\title{
Pengaruh Keaktifan Belajar, Kemandirian Dan Kreativitas Terhadap Prestasi Belajar Matematika Siswa Kelas IX SMP
}

\author{
Aisyah Hariyani Achmad ${ }^{1, a)}$, Muhammad Dinar ${ }^{1}$, dan Bernard ${ }^{1}$ \\ ${ }^{1}$ Jurusan Matematika, Fakultas MIPA, Universitas Negeri Makassar \\ a) aisyahhariyani37@gmail.com
}

\begin{abstract}
Abstrak. Penelitian ini adalah penelitian ex-post facto yang bertujuan untuk mengetahui adanya pengaruh antara keaktifan belajar, kemandirian dan kreativitas terhadap prestasi belajar matematika siswa kelas IX SMP. Sampel dipilih secara acak dari populasi sebanyak tiga kelas dari sembilan kelas. Pengambilan data dilakukan dengan menggunakan angket dan tes prestasi belajar. Data tersebut dianalisis secara deskriptif dan inferensial. Hasil penelitian secara deskriptif diperoleh (1) Prestasi belajar matematika siswa berada pada kategori tinggi, (2) Keaktifan belajar berada pada kategori tinggi, (3) Kemandirian belajar berada pada kategori tinggi, (4) Kreativitas belajar berada pada kategori rendah. Secara inferensial diperoleh (1) Terdapat pengaruh antara keaktifan belajar, kemandirian belajar dan kreativitas belajar secara bersama-sama terhadap prestasi belajar matematika siswa, (2) Terdapat pengaruh signifikan antara keaktifan belajar terhadap prestasi belajar belajar matematika siswa dengan memperhatikan kemandirian belajar dan kreativitas belajar kelas, (3) Terdapat pengaruh signifikan antara kemandirian belajar terhadap prestasi belajar belajar matematika siswa dengan memperhatikan keaktifan belajar dan kreativitas belajar, (4) Tidak terdapat pengaruh signifikan antara kreativitas belajar terhadap prestasi belajar belajar matematika siswa dengan memperhatikan keaktifan belajar dan kemandirian belajar.
\end{abstract}

Kata kunci : Keaktifan Belajar, Kemandirian, Kreativitas, Prestasi Matematika

\begin{abstract}
Abstrack. This study was ex-post facto research, which purposed to know the influences of learning activeness, independence and creativity toward Students' Mathematics Learning Achievement on grade IX of SMP. Sample of study was chosen randomly three class from nine classes. Data were collected using the questionnaires and test learning achievement. The data were analyzed by Descriptive and Inferential. Descriptive analyze obtain (1) Students' mathematics learning achievement are at high category, (2) Learning activeness are at high category, (3) Learning independence are at high category, (4) Learning creativity are at low category. Inferentially acquire (1) There is influences of learning activeness, learning independence and learning creativity together towards students' mathematics learning achievement, (2) There is a positive influence of learning activeness toward students' mathematics learning achievement by paying attention to the learning independence and learning creativity, (3) There is a positive influence of learning independence toward students' mathematics learning achievement by paying attention to the learning activeness and learning creativity, (4) There was no influence of learning creativity toward students' mathematics learning achievement by paying attention to the learning activeness and learning independence.
\end{abstract}

Keyword : Learning Activeness, Independence, Creativity, Mahtematics Achievement 


\section{PENDAHULUAN}

Faktor-faktor yang dapat mempengaruhi prestasi belajar umumnya terbagi atas faktor internal dan faktor eksternal. Faktor-faktor yang mempengaruhi prestasi belajar siswa di sekolah secara garis besar dapat dibagi tiga bagian, yaitu faktor internal, faktor eksternal dan faktor pendekatan belajar (Syah, 2010). Faktor internal terdiri atas faktor fisiologis dan faktor psikologis. Adapun yang termasuk faktor fisiologis yaitu faktor yang berkaitan dengan keadaan fisik, sementara faktor psikologis yaitu inteligensi, perhatian, minat, motivasi, bakat dan lain sebagainya.

Diantara faktor psikologis yang dapat mempengaruhi prestasi belajar, penelitian ini berfokus pada tiga faktor yaitu keaktifan belajar, kemandirian dan kreativitas siswa. Oleh karena itu, peneliti ingin melihat pengaruh faktor keaktifan belajar, kemandirian dan kreativitas terhadap prestasi belajar matemtika.

Adapun penelitian lain yang mendukung diantaranya penelitian oleh Defika (2015) yang mengemukakan bahwa terdapat pengaruh yang signifikan antara keaktifan belajar terhadap prestasi belajar matematika siswa kelas VII. Kemudian, penelitian oleh Azis (2018) yang menyatakan bahwa kemandirian belajar berpengaruh positif terhadap prestasi belajar matematika siswa kelas XI MIPA. Adapula penelitian oleh Mutmainna (2011) mengemukakan bahwa kreativitas belajar siswa berpengaruh terhadap hasil belajar matematika siswa.

\section{KAJIAN PUSTAKA}

\section{Keaktifan Belajar}

Keaktifan belajar adalah adanya aktivitas siswa selama pembelajaran meliputi beberapa hal, yaitu perhatian, kerjasama dan hubungan sosial, mengemukakan gagasan, pemecahan masalah dan disiplin (Achdiyat \& Lestari, 2016). Senada dengan yang dikemukakan oleh Firdawati \& Hidayat (2018) bahwa keaktifan belajar merupakan aktivitas dalam kegiatan belajar yang dilakukan siswa, dimulai dari mengamati dan menyelidiki sendiri, serta bekerja aktif dengan fasilitas yang diciptakan sendiri untuk berkembang dengan bimbingan dan pengamatan dari guru.

Keaktifan belajar siswa sangat mempengaruhi prestasi belajar siswa, baik aktif bertanya maupun aktif menjawab pertanyaan guru, secara tidak langsung akan berpengaruh dengan prestasi belajar siswa. Siswa yang aktif di kelas akan cenderung memiliki prestasi yang lebih baik dibandingkan siswa yang kurang aktif dikelas (Prasetya, 2012; Defika, 2015; Budianto, 2016; Kurniawati, 2017; Rahmayati, 2017; Firdawati dan Hidayat, 2018; Purwaningsih, 2018) . Defika (2015) mengemukakan bahwa terdapat pengaruh yang signifikan antara keaktifan belajar terhadap prestasi belajar matematika siswa kelas VII. Sedangkan, Kurniawati (2017) menyatakan bahwa keaktifan belajar siswa berpengaruh positif terhadap hasil belajar siswa kelas VIII. Sementara, Purwaningsih (2018) juga mengemukakan bahwa keaktifan belajar berpengaruh signifikan terhadap hasil belajar siswa kelas XI bidang Ilmu Sosial.

\section{Kemandirian Belajar}

Kemandirian merupakan salah satu segi dari sifat seseorang. Menurut Martinis (2007) kemandirian belajar merupakan perilaku individu yang mampu berinisiatif, mampu mengatasi masalah, mempunyai rasa percaya diri, bertanggungjawab dan dapat melakukan sesuatu sendiri tanpa bergantung pada orang lain dalam belajar. Sejalan dengan yang diungkapkan oleh Suhendri (2011) kemandirian belajar adalah suatu aktivitas belajar yang dilakukan siswa tanpa bergantung pada teman maupun gurunya dalam mencapai tujuan belajar dan dapat mengaplikasikan pengetahuannya dalam menyelesaikan masalah dalam kehidupan sehari-hari. 
Zimmerman, Bonner \& Kovach (1996) mengemukakan bahwa latihan kemandirian belajar dapat meningkatkan semangat siswa dan guru dengan meningkatkan partisipasi siswa dalam kelas, kualitas diskusi, dan ketertarikan siswa terhadap topik pelajaran. Siswa yang memiliki kemandirian dalam belajar cenderung memiliki prestasi belajar yang lebih baik (Suhendri, 2011; Abriyani, 2012; Prayuda, 2014; Ningsih \& Nurrahmah, 2016; Rusmiyati, 2017; Azis, 2018) . Ningsih \& Nurrahmah (2016) menyatakan bahwa terdapat pengaruh positif yang signifikan kemandirian belajar terhadap prestasi belajar matematika. Sejalan dengan itu, Rusmiyati (2017) mengemukakan bahwa terdapat pengaruh yang positif dan signifikan antara kemandirian belajar dengan prestasi belajar matematika siswa kelas X SMA. Azis (2018) juga menyatakan bahwa kemandirian belajar berpengaruh positif terhadap prestasi belajar matematika siswa kelas XI MIPA SMA.

\section{Kreativitas Belajar}

Kreativitas merupakan kemampuan dasar dalam belajar matematika karena matematika banyak menyajikan fakta. Munandar (2004) mengatakan bahwa Kreativitas adalah kemampuan untuk membuat kombinasi baru berdasarkan data informasi atau unsur yang ada, berdasarkan data atau informasi yang tersedia, menemukan banyak kemungkinan jawaban terhadap suatu masalah, dimana penekanannya adalah pada kualitas, ketepat gunaan dan keragaman jawaban yang mencerminkan kelancaran, keluwesan dan orisinalitas dalam berfikir serta kemampuan untuk mengelaborasi suatu gagasan.

Kreativitas belajar pada siswa sangat mempengaruhi prestasi belajar siswa. Siswa yang mempunyai kreativitas belajar matematika tinggi akan mampu menciptakan ide-ide sebagai alternatif untuk menyelesaikan permasalahan, secara tidak langsung akan berpengaruh pada prestasi belajar siswa. Siswa yang memiliki kreativitas dalam belajar yang tinggi akan cenderung memiliki prestasi yang tinggi pula (Mutmainna, 2011; Haryanti, 2012; Amalia, 2015; Jabar dan Budiarti, 2016; Istiqomah, 2017). Mutmainna (2011) mengemukakan bahwa kreativitas belajar siswa berpengaruh terhadap hasil belajar matematika siswa. Sementara penelitian oleh Amalia (2015) menunjukkan bahwa terdapat pengaruh yang signifikan kreativitas belajar siswa terhadap hasil belajar matematika. Sejalan dengan itu, Istiqomah (2017) juga menyatakan bahwa ada pengaruh yang positif dan signifikan antara kreativitas terhadap prestasi belajar siswa.

\section{METODE PENELITIAN}

Jenis penelitian yang digunakan adalah jenis penelitian ex post facto, penelitian dilaksanakan di kelas IX pada salah satu SMP. Sampel dalam penelitian ini terdiri dari 77 siswa. Instrumen yang digunakan yaitu angket keaktifan belajar, kemandirian belajar, kreativitas dan tes prestasi belajar matematika yang telah divalidasi oleh dua orang ahli.

Adapun kategori setiap variabel dalam penelitan ini sebagai berikut.

TABEL 1. Kategori Keaktifan Belajar

\begin{tabular}{ccl}
\hline No. & Rentang Skor & \multicolumn{1}{c}{ Kategori } \\
\hline 1 & $X \leq 28$ & Sangat Rendah \\
2 & $28<X \leq 35$ & Rendah \\
3 & $35<X \leq 42$ & Tinggi \\
4 & $X>42$ & Sangat Tinggi \\
\hline
\end{tabular}


TABEL 2. Kategori Kemandirian Belajar

\begin{tabular}{ccl}
\hline No. & Rentang Skor & \multicolumn{1}{c}{ Kategori } \\
\hline 1 & $X \leq 28$ & Sangat Rendah \\
2 & $28<X \leq 35$ & Rendah \\
3 & $35<X \leq 42$ & Tinggi \\
4 & $X>42$ & Sangat Tinggi \\
\hline \multicolumn{3}{r}{ TABEL 3. Kategori Kreativitas Belajar } \\
\hline No. & Rentang Skor & \multicolumn{1}{c}{ Kategori } \\
\hline 1 & $X \leq 30$ & Sangat Rendah \\
2 & $30<X \leq 37,5$ & Rendah \\
3 & $37,5<X \leq 45$ & Tinggi \\
4 & $X>45$ & Sangat Tinggi \\
\hline
\end{tabular}

TABEL 4. Kategori Prestasi Belajar Matematika

\begin{tabular}{ccl}
\hline No. & Interval Nilai & \multicolumn{1}{c}{ Kategori } \\
\hline 1 & Skor $<40$ & Sangat Rendah \\
2 & $40 \leq$ skor $<55$ & Rendah \\
3 & $55 \leq$ skor $<70$ & Sedang \\
4 & $70 \leq$ skor $<85$ & Tinggi \\
5 & $85 \leq$ skor $\leq 100$ & Sangat Tinggi \\
\hline
\end{tabular}

Analisis data yang digunakan pada penelitian ini yaitu analisis statistik deskriptif dan analisis statistik inferensial. Analisis statistik dekriptif digunakan untuk mendeskripsikan setiap variabel penelitian yaitu keaktifan belajar, kemandirian belajar, kreativitas belajar dan prestasi belajar matematika siswa. Hasil analisis statistik deskriptif meliputi tabel distribusi frekuensi, mean, variansi, standar deviasi, dan perhitungan persentase.

Analisis statistik inferensial digunakan untuk menguji hipotesis penelitian. Adapun hipotesis dalam penelitian ini yaitu terdapat pengaruh secara bersama-sama keaktifan belajar, kemandirian belajar, dan kreativitas belajar terhadap Prestasi belajar matematika siswa kelas IX SMP. Metode analisis yang digunakan dalam penelitian ini adalah analisis kuantitatif dengan analisis regresi linear berganda (multiple linear analysis) pada taraf kepercayaan $95 \%(\alpha=0,05)$, namun sebelumnya dilakukan uji prasyarat yaitu uji nornalitas, uji heteroskedastisitas dan uji multikolinearitas.

\section{HASIL DAN PEMBAHASAN}

\section{Analisis Statistik Deskriptif}

TABEL 5. Distribusi Frekuensi Skor Keaktifan Belajar

\begin{tabular}{cccc}
\hline Rentang Skor & Kategori & Frekuensi & Persentase (\%) \\
\hline$X \leq 28$ & Sangat Rendah & 2 & 2,60 \\
$28<X \leq 35$ & Rendah & 14 & 18,18 \\
$35<X \leq 42$ & Tinggi & 37 & 48,05 \\
$X>42$ & Sangat Tinggi & 24 & 31,17 \\
\hline & Jumlah & 77 & 100 \\
\hline
\end{tabular}

Pada Tabel 5, terlihat bahwa terdapat 2 siswa yang berada pada kategori sangat rendah, sedangkan 24 siswa berada pada kategori sangat tinggi. Namun, secara umum keaktifan belajar siswa berada pada kategori tinggi dengan persentase sebesar $48,05 \%$. 
IMED 4(1) 2020, hal. $11-17$

TABEL 6. Distribusi Frekuensi Skor Kemandirian Belajar

\begin{tabular}{cccc}
\hline Rentang Skor & Kategori & Frekuensi & Persentase (\%) \\
\hline$X \leq 28$ & Sangat Rendah & 1 & 1,30 \\
$28<X \leq 35$ & Rendah & 20 & 25,97 \\
$35<X \leq 42$ & Tinggi & 40 & 51,95 \\
$X>42$ & Sangat Tinggi & 16 & 20,78 \\
\hline & Jumlah & 77 & 100 \\
\hline
\end{tabular}

Pada Tabel 6, dapat ditinjau bahwa terdapat 1 siswa yang berada pada kategori sangat rendah, sedangkan 16 siswa berada pada kategori sangat tinggi. Namun, secara umum kemandirian belajar siswa berada pada kategori tinggi dengan persentase sebesar 51,95\%.

TABEL 7. Distribusi Frekuensi Skor Kreativitas Belajar

\begin{tabular}{cccc}
\hline Rentang Skor & Kategori & Frekuensi & Persentase (\%) \\
\hline$X \leq 30$ & Sangat Rendah & 4 & 5,20 \\
$30<X \leq 37,5$ & Rendah & 39 & 50,64 \\
$37,5<X \leq 45$ & Tinggi & 30 & 38,96 \\
$X>45$ & Sangat Tinggi & 4 & 5,20 \\
\hline & Jumlah & 77 & 100 \\
\hline
\end{tabular}

Tabel 7, menunjukkan bahwa terdapat 4 siswa yang berada pada kategori sangat rendah, sedangkan 4 siswa juga berada pada kategori sangat tinggi. Namun, secara umum kreativitas belajar siswa berada pada kategori rendah dengan persentase sebesar 50,64\%.

TABEL 8. Distribusi Frekuensi Skor Prestasi Belajar Matematika

\begin{tabular}{cccc}
\hline Interval Nilai & Kategori & Frekuensi & Persentase (\%) \\
\hline Skor $<40$ & Sangat Rendah & 0 & 0 \\
$40 \leq$ skor $<55$ & Rendah & 12 & 15,58 \\
$55 \leq$ skor $<70$ & Sedang & 16 & 20,78 \\
$70 \leq$ skor $<85$ & Tinggi & 33 & 42,86 \\
$85 \leq$ skor $\leq 100$ & Sangat Tinggi & 16 & 20,78 \\
\hline & Jumlah & 77 & 100
\end{tabular}

Pada Tabel 8, terlihat bahwa tidak terdapat siswa yang berada pada kategori sangat rendah, sedangkan 16 siswa berada pada kategori sangat tinggi. Namun, secara umum kemandirian belajar siswa berada pada kategori tinggi dengan persentase sebesar $42,86 \%$.

\section{Analisis Statistik Inferensial}

Nilai signifikan yang diperoleh adalah 0,097. Nilai signifikan sebesar 0,097 lebih kecil dari nilai alpha 0,05 sehingga data berdistribusi normal. Uji multikolinearitas dilihat dari nilai Variance Inflation Factor (VIF). Pada model regresi, nilai VIF untuk keaktifan belajar yang diperoleh sebesar 1,613. Kemandirian belajar diperoleh nilai VIF sebesar 2,292. Sementara, kreativitas belajar diperoleh nilai VIF sebesar 1,790. Artinya model regresi tersebut bebas multikolinearitas karena nilai VIF yang diperoleh kurang dari 10 atau dapat dikatakan bahwa tidak terjadi multikolinearitas.

Pada uji heteroskedastisitas, diperoleh nilai signifikan untuk keaktifan belajar sebesar 0,165, kemandirian belajar diperoleh nilai signifikan sebesar 0,331. Sedangkan, kreativitas belajar memperoleh nilai signifikan sebesar 0,453. Maka, dapat dikatakan bahwa model regresi tidak mengandung adanya heteroskedastisitas, karena nilai signifikan yang diperoleh lebih dari 0,05 atau dapat dikatakan bahwa tidak terjadi heteroskedastisitas.

Setelah uji prasyarat, selanjutnya dilakukan uji hipotesis. Pada uji hipotesis, diperoleh persamaan regresi liear ganda yaitu $Y=3,614+0,799 X_{1}+0,879 X_{2}+0,021 X_{3}$. Dimana, keaktifan belajar, kemandirian belajar dan kreativitas belajar $\left(\mathrm{X}_{1}, \mathrm{X}_{2}\right.$ dan $\left.\mathrm{X}_{3}\right)$. Sedangkan, $\mathrm{Y}$ 
merupakan prestasi belajar matematika. Hal ini menunjukkan bahwa kenaikan satu unit $X_{1}$ akan mengakibatkan 0,799 unit kenaikan $\mathrm{Y}$, kenaikan satu unit $\mathrm{X}_{2}$ akan mengakibatkan 0,879 unit kenaikan $\mathrm{Y}$ dan kenaikan satu unit $\mathrm{X}_{3}$ akan mengakibatkan 0,021 unit kenaikan Y. Dari hasil uji hipotesis, juga diperoleh nilai $\rho$ sebesar 0,000 yang lebih kecil dari nilai $\alpha$ yaitu 0,05 . Maka, dapat dikatakan bahwa terdapat pengaruh secara bersama-sama antara keaktifan belajar, kemandirian belajar dan kreativitas belajar siswa terhadap prestasi belajar matematika siswa kelas IX SMP.

\section{KESIMPULAN}

Tujuan dari penelitian ini untuk melihat apakah ada pengaruh antara keaktifan belajar, kemandirian dan kreativitas terhadap prestasi belajar matematika siswa. Keaktifan belajar, kemandirian belajar dan prestasi belajar matematika siswa berada dalam kategori tinggi sedangkan kreativitas belajar siswa kelas termasuk dalam kategori rendah.

Keaktifan belajar berpengaruh terhadap prestasi belajar matematika siswa. Sementara, kemadirian belajar berpengaruh terhadap prestasi belajar matematika siswa. Sedangkan, kreativitas belajar juga berpengaruh terhadap prestasi belajar matematika siswa. Sementara, secara simultan (bersama-sama) berpengaruh signifikan terhadap prestasi belajar matematika siswa kelas IX SMP.

\section{DAFTAR PUSTAKA}

Abriyani, R. (2012). Pengaruh Kemandirian Belajar dan Lingkungan Belajar terhadap Prestasi Belajar IPS Siswa Kelas V SDN 04 Tegalgede Tahun Pelajaran 2011/2012. (Skripsi, tidak dipublikasikan). Universitas Muhammadiyah Surakarta, Surakarta.

Achdiyat, M. \& Lestari, K.D. (2016). Prestasi Belajar Matematika Ditinjau dari Kepercayaan Diri dan Keaktifan Siswa di Kelas. Jurnal Formatif, 6 (1). 50-61.

Amalia, N. (2015). Pengaruh Teknik Pembelajaran dan Kreativitas Belajar Siswa terhadap Hasil Belajar Matematika. JKPM, 1 (1). 31-45.

Azis, A.F.H. (2018). Pengaruh Kebiasaan Belajar, Gaya Belajar, Kepercayaan Diri, dan Kemandirian Belajar terhadap Prestasi Belajar Matematika Siswa Kelas XI MIPA SMA Negeri 8 Makassar. (Skripsi, tidak dipublikasikan). Universitas Negeri Makassar, Makassar.

Budianto, A. (2016). Hubungan Gaya Belajar dan Keaktifan Belajar terhadap Prestasi Belajar pada Mata Pelajaran Gambar Teknik di SMK PIRI Sleman. (Skripsi, tidak dipublikasikan). Universitas Negeri Yogyakarta, Yogyakarta.

Defika, S. (2015). Pengaruh Kedisiplinan dan Keaktifan Belajar Siswa terhadap Prestasi Belajar Matematika Siswa Kelas VII MTs Negeri Karangrejo Tulungagung Tahun Ajaran 2014/2015 (Skripsi, tidak dipublikasikan). Institut Agama Islam Negeri (IAIN), Tulungagung.

Firdawati, I. \& Hidayat, W. (2018). Hubungan antara Keaktifan Belajar Siswa terhadap Kemampuan Komunikasi Matematis Siswa SMK. Jurnal Visipena, 9 (1). 151-158.

Haryanti. (2012). Pengaruh Gaya Belajar dan Kreativitas Siswa terhadap Prestasi Belajar Matematika Kelas VIII SMPN 1 Selogiri Tahun 2011/2012. (Skripsi, tidak dipublikasikan). Universitas Muhammadiyah Surakarta, Surakarta.

Istiqomah, M.N. (2017). Pengaruh Gaya Belajar dan Kreativitas terhadap Prestasi Belajar Siswa Kelas V SD Se-Gugus Mardisiswa Kecamatan Gumelar Kabupaten Banyumas. (Skripsi, tidak dipublikasikan). Universitas Negeri Semarang, Semarang. 
Jabar, A. \& Budiarti, I. (2016). Pengaruh Kreativitas terhadap Hasil Belajar Matematika Siswa Kelas VIII SMPN 2 Banjarmasin. Math Didactic: Jurnal Pendidikan Matematika, 2 (2). 85-90.

Kurniawati, C. (2017). Pengaruh Keaktifan Belajar dan Motivasi Belajar terhadap Hasil Belajar Siswa Kelas VIII B SMP Kanisius Kalasan pada Topik Bahasan Operasi Aljabar menggunakan Model Pembelajaran Kooperatif tipe Jigsaw II Tahun Ajaran 2016/2017. (Skripsi, tidak dipublikasikan). Universitas Sanata Dharma, Yogyakarta.

Martinis , Y. (2007). Desain Pembelajaran Berbasis Tingkat Satuan Pendidikan. Jakarta: Gaung Persada Press.

Munandar, U. (2004). Pengembangan Kreativitas Anak Berbakat. Jakarta: Rineka Cipta.

Mutmainna. (2011). Pengaruh Minat dan Kreativitas Belajar Matematika terhadap Hasil Belajar Matematika Siswa Kelas VIII MTs.N 410 Tanete Kab. Bulukumba. (Skripsi, tidak dipublikasikan). Universitas Negeri Makassar, Makassar.

Ningsih, R. \& Nurrahmah, A. (2016). Pengaruh Kemandirian Belajar dan Perhatian Orang Tua terhadap Prestasi Belajar Matematika. Jurnal Formatif, 6 (1). 73-84.

Prasetya, D. (2012). Hubungan Keaktifan dan Kedisiplinan Belajar Siswa terhadap Prestasi Belajar Matematika pada Siswa Kelas X SMA Muhammadiyah 4 Kartasura. (Skripsi, tidak dipublikasikan). Universitas Muhammadiyah Surakarta, Surakarta.

Prayuda, R. (2014). Pengaruh Kemandirian Belajar terhadap Hasil Belajar Siswa pada Mata Pelajaran Ekonomi di SMA. (Skripsi, tidak dipublikasikan). Universitas Tanjungpura, Pontianak.

Purwaningsih, S. (2018). Pengaruh Keaktidan dan Motivasi terhadap Hasil Belajar Siswa dalam Penerapan Model Pembelajaran Kooperatif tipe STAD Materi Turunan Fungsi pada Siswa Kelas XI IS 2 SMAN 15 Semarang. Jurnal Karya Pendidikan Matematika, 5 (2). 63-67.

Rahmayati, N.A. (2017) Pengaruh Keaktifan Siswa terhadap Hasil Belajar Materi Operasi Hitung Pecahan menggunakan Model Pembelajaran Kooperatif Tipe Talking Stick Siswa Kelas VII SMP Negeri 2 Papar Tahun 2016/2017. (Skripsi, tidak dipublikasikan). Universitas Nusantara PGRI Kediri, Kediri.

Rusmiyati, F. (2017). Pengaruh Kemandirian dan Kebiasaan Belajar terhadap Prestasi Belajar Matematika Siswa Kelas X SMA Negeri 1 Rongkop. UNION: Jurnal Pendidikan Matematik, 5 (1). 77-85.

Suhendri, H. (2011). Pengaruh Kecerdasan Matematis Logis dan Kemandirian Belajar terhadap Hasil Belajar Matematika. Jurnal Formatif, 1 (1). 29-39.

Syah, M. (2010). Psikologi Pendidikan dengan Pendekatan Baru. Bandung: PT. Remaja Rosda Kaya.

Zimmerman, B.J., Bonner, S. \& Kovach, R. (1996). Developing Self-Regulated Learners Beyond Achievement to Self-Efficacy. Washington, DC: American Psychological Association. 